\title{
When stakeholder theory meets justification theory: an intersection proposal
}

\author{
Helna Almeida de Araujo Góes ${ }^{1}$ \\ Germano GLUfKe ReIS ${ }^{1}$ \\ GuStAVo ABIB ${ }^{1}$
}

\author{
${ }^{1}$ Universidade Federal do Paraná (UfPr) / Business Management Graduate Program, Curitiba - PR, Brazil
}

\begin{abstract}
We discuss an interplay between two theories by addressing the question: In what ways can the Justification theory (JT) complement the Stakeholder theory (ST)? While ST provides an insight on the importance of creating value for stakeholders without resorting to tradeoffs, it does not address how several stakeholders employ justifications to achieve their goals, nor does it explore the analytical thinking on how organizations and their stakeholders account for and negotiate behaviors during disputes. The JT provides a framework that interprets social interactions and tensions by considering that actors' decisions and actions are contextualized within organizational reality. Several studies that apply the JT framework in the context of organizations do so by directly or indirectly analyzing stakeholders. Hence, this essay sheds light on how such an intersection may help to comprehend the phenomena related to disputes. The study offers tools and contributes to understanding managerial practices for stakeholders identification and engagement since, to the best of our knowledge, there is a research gap regarding the intersection between JT and ST.
\end{abstract}

Keywords: Stakeholder theory. Justification theory. Management practices. Public controversies.

\section{Quando a teoria dos stakeholders encontra a teoria da justificação: uma proposta de interseção}

\section{Resumo}

Discutimos uma interação entre duas teorias, abordando a questão: De quais formas a teoria da Justificação (TJ) pode complementar a teoria dos stakeholders (ST)? Embora a ST forneça uma visão sobre a importância de criar valor para as partes interessadas sem recorrer a tradeoffs, não aborda como várias partes interessadas empregam justificativas para alcançar os seus objetivos; nem explora o pensamento analítico sobre a forma como as organizações e as seus stakeholders respondem e negociam comportamentos durante situações de disputa. A TJ fornece um modelo que interpreta as interações e tensões sociais, considerando que as decisões e ações dos atores são contextualizadas dentro da realidade organizacional. Vários estudos que aplicam o modelo da TJ no contexto das organizações fazem-no analisando direta ou indiretamente os stakeholders; alguns estudos anteriores são aqui retratados. Dessa forma, este ensaio lança luz sobre como tal interseção pode melhorar a compreensão de fenômenos relacionados com situações de disputa. Além disso, o nosso objetivo é contribuir para a compreensão, bem como fornecer ferramentas para facilitar práticas de gestão no que diz respeito à identificação e envolvimento dos stakeholders, na medida em que, sobre o que conhecemos, não há pesquisa suficiente aplicando a interseção aqui proposta.

Palavras-chave: Teoria dos stakeholders. Teoria da justificação. Práticas de gestão. Controvérsias públicas.

\section{Cuando la teoría de los stakeholders se encuentra con la teoría de la justificación: una propuesta de intersección}

\section{Resumen}

Discutimos una interacción entre dos teorías al abordar la cuestión: ¿De qué manera la teoría de la justificación (TJ) puede complementar la teoría de los stakeholders (ST)? Si bien la ST proporciona una idea de la importancia de crear valor para los stakeholders sin recurrir a compensaciones, no aborda la forma en que varios interesados emplean justificaciones para alcanzar sus objetivos; tampoco explora el pensamiento analítico sobre la forma en que las organizaciones y sus stakeholders dan cuenta y negocian los comportamientos durante las situaciones de controversia. La TJ proporciona un marco que interpreta las interacciones y tensiones sociales considerando que las decisiones y acciones de los actores están contextualizadas dentro de la realidad organizacional. Varios estudios que aplican el modelo de la TJ en el contexto de las organizaciones lo hacen mediante el análisis directo o indirecto de los interesados; en el presente documento se describen algunos estudios anteriores. De ahí que este ensayo arroje luz sobre la forma en que esa intersección puede mejorar la comprensión de los fenómenos relacionados con las situaciones de conflicto. Además, pretendemos contribuir a la comprensión y proporcionar instrumentos para facilitar la práctica de la gestión en lo que respecta a la identificación y participación de los interesados, ya que, hasta donde sabemos, no hay suficientes investigaciones que apliquen la intersección aquí propuesta.

Palabras clave: Teoría de los stakeholders. Teoría de la justificación. Prácticas de gestión. Controversias públicas. 


\section{INTRODUCTION}

The Stakeholder theory (ST) focuses on how the relationship between an organization and its stakeholders is developed and managed to create value without resourcing to tradeoffs while maximizing value creation for all parties (Freeman, 2010a). Its core premise is that managers must account for stakeholders' interests in order to engage in a more effective and sustainable decision-making process. Value is mainly employed as a synonym of economic benefits, i.e., profits. However, besides creating economic value for all parties involved, creating value for stakeholders also includes non-economic benefits. For instance, employees may seek psychological benefits such as recognition, satisfaction and/or learning (Argandoña, 2011).

In other words, ST provides tools to identify stakeholders and analyze their interests to negotiate with them (Freeman, 2010b). Previous literature addressed different approaches to the managers' challenges to identify and assess stakeholders' salience (Driscoll \& Starik, 2004; Mitchell, Agle \& Wood, 1997; Wood, Mitchell, Agle \& Bryan, 2018).

Managers must be aware of their reality and evaluate how stakeholders differ from each other, due to economic, political, social, and cultural factors. Stakeholders and the organization are interdependent. This directly impacts the strategy formulation process, as it allows managers to incorporate values and principles to give temporary stability to relations with stakeholders.

Alignment among - often divergent - interests may (in)directly, lead to better organizational performance (Barney \& Harrison, 2020; Crane, 2020; Freeman, 2004; Harrison, Freeman \& Abreu, 2015). Thus, ST encourages ethical management practices (Donaldson \& Preston, 1995; Freeman, Phillips \& Sisodia, 2020). However, tools for accurately account for stakeholders' interests remain obscure. Stakeholder theory has benefitted from having contributions from other fields of knowledge such as sociology (Harrison et al., 2015; Phillips, Barney, Freeman \& Harrison, 2019).

Such understanding of the strategies and behaviors adopted by organizations when considering the importance and influence that stakeholders exert on the formulation and execution of the strategy provides an ethical interpretation of the relationships, i.e., interactions among different groups within a specific context that directly influence the achievements of organizational goals (Barney et al., 2019; Harrison et al., 2015). Therefore, the organization also should create value for its stakeholders without resourcing to tradeoffs, envisioning a sustainable relationship while seeking to satisfy several stakeholders' demands simultaneously without compromising organizational interests (Bundy \& Pfarrer, 2015; Mascena \& Stocker, 2020; Stocker \& Mascena, 2019; Sulkowski, Edwards \& Freeman, 2018).

To better understand how such interactions take place (are made, prioritized and/or negotiated) and conflicts therefrom unfold, is a way to better understand how organizational reality is enabled or constrained (Dorobantu, 2019; Parmar et al., 2010); hence this constitutes the justification of the herein proposed interplay between Stakeholder theory and Justification theory.

Justification theory (JT) attempts to analyze the different situations that demand different action regimes and their justifications (Giulianotti \& Langseth, 2016). It argues for using a pragmatic linguistic view in which the actors, embedded in uncertain and ambiguous situations, use grammatical resources to cope with and guide such situations (Boltanski \& Thévenot, 2006).

The JT proposes a framework that analyzes the interactions between individuals starting from the premise that such interactions require the use of justifications. Such justifications, in turn, result from situations of disagreement that are present in social reality, and therefore in organizational life. For this pursuit, JT enables us to map several "orders of worth" (worlds of value), differentiated by a single principle of value based on the concept of "common good", ie, on what is useful to all people, to the society as a whole (Argandoña, 1998) and that enables associations among beings (Boltanski \& Thévenot, 2006).

Value is a feature that assesses the qualification of beings in situations of dispute. Seeking legitimate, i.e., non-violent, ways to reach an outcome requires that qualified beings engage in legitimate negotiations.

In order to live between these worlds, individuals, groups, and/or organizations must use justifications that explain their decisions and actions (Boltanski \& Thévenot, 2006; Giulianotti \& Langseth, 2016). These justifications may prioritize, for instance, either market-driven arguments (market world) or environmental concerns (the green world) (Giulianotti \& Langseth, 2016; Thévenot, Moody \& Lafaye, 2000). 
The JT focuses on contexts involving disagreements regarding conflicting points of view among actors (organizations and stakeholders) and how those actors elaborate or/and modify their discourses in order to justify their situational decisions and actions. Those situations may emerge, for instance, in the processes of the positioning of products such as the Baltic Salmon (Ignatius \& Haapasaari, 2018) or, it may be applied in contexts of environmental issues such as debates regarding nature conservation practices (Arts, Buijs \& Verschoor, 2018), or understanding organizational strategy concerning legitimacy negotiation among different stakeholders in events of disasters or (nuclear) accidents (Patriotta, Gond \& Schultz, 2011).

In order words, it is herein proposed an interplay with Justification theory in the following way: the analysis of justifications employed in situations of dispute may be a tool used to enhance managers' accurate identification and analysis of stakeholders' interests. Thus, it is a tool that may leverage negotiations, impacting the alignment of interests. It is also a fruitful tool for scholars as it provides an interpretation of moral principles that emerge from management practices.

To this end, we analyze previous studies that examine the decisions and actions of stakeholders in light of the JT framework, showing how the proposed intersection takes place. Managing stakeholders is a challenge since it requires accurately identify and manage multiple expectations (Brondoni et al., 2020). This proposal argues that by analyzing stakeholders' justifications, it is possible to assist managers in identifying stakeholder salience and negotiating with them, which may mitigate the negative effects of managing multiple expectations.

Therefore, our paper contributes to the ST literature by moving forward and deepening the understanding of justifications used by organizations and their stakeholders during disruptive organizational situations, ie. situations that impose actors to negotiate or renegotiate courses of action aiming at reaching agreements (e.g., organizational change, innovation, environmental accident) (Gioia \& Chittipeddi, 1991; Isabella, 1990; Patriotta et al., 2011). Moreover, to the best of our knowledge, the use of the combination of theories to analyze organizational phenomena has been overlooked so far (Jagd, 2011).

Our proposal has practical implications for managers attempting to establish sustainable relations with their stakeholders while creating value for both parties involved. Organizational survival and performance are dependent on the alignment between the organization and its stakeholders. By interpreting stakeholders' justifications, managers are able to assess the salience of claims in a given situation, to evaluate their interests and thus, to negotiate with them while seeking an alignment with all the involved parties. Our proposal illustrates a feasible way to achieve such alignment. Also by interpreting justifications it is possible to foresee, to some extent, future decisions or actions related to certain issues (Mills, 1940; Schneider \& Sachs, 2017).

Our conceptual paper is structured as follows. First, we explain our epistemology premise, then we highlight the ST key concepts for our purpose, the same is done for JT. Whereupon, we highlight a theme for the feasibility of such intersection and we briefly discuss previous studies that were chosen because they approach controversies, i.e., dispute situations and they provide a peculiar analysis applying JT. The intent of displaying brief descriptions of studies is to indicate the possibilities of using JT in stakeholder-related research. Lastly, we provide our core arguments of how and why such an intersection is relevant to stakeholder-related research while discussing our proposal's limitations and suggesting future research developments.

\section{What grounds our intersection proposal?}

The relationship between an organization and its environment influences insights that are observed and applied within management studies. The environment and the organization are characterized as enacted, grounded in interpretative sociology, and cognitive-social epistemology that understands the organization and its environment are created together through processes of social interaction of key participants. Therefore, there is a combination of thoughts and actions; the environment is perceived in light of the way the strategist makes sense of it (Smircich \& Stubbart, 1985).

Both theories accentuate the actors' agency once they have the capacity to interpret situations and act based on it. Regarding ST, the manager must be able to interpret a situation and also the interests of different stakeholders in order to reach an alignment (Donaldson \& Preston, 1995; Freeman, 2010a, 2010b; Freeman, Harrison, Wicks, Parmar \& Colle, 2010). Concerning $\mathrm{JT}$, competent beings must act on situations of dispute, providing justifications to reach a situation of agreement or compromise (Boltanski \& Thevenot, 1999, 2006; Dequech, 2008). 
Moreover, the philosophical concept of "common good" is intertwined in both theories and underpins our intersection proposal. The "common good" may be understood as a principle that is good to all people, to the society as a whole. It is everything that belongs equally to all individuals, thus it is equally communicated to or shared among members of a society and enables the "individual good" (Argandoña, 1998; Eranti, 2018).

Regarding ST, the "common good" provides its main foundation and enables its core ethical premises, the organization must "do good" to individuals or/and groups who have a "stake" in its interests as well as weighting the impacts of its activities on the society by observing a concern for future generations (Argandoña, 1998). Concerning JT, the "common good" provides its core argument related to the ideals of justice that is superior to individuals and enables concordances between them in situations of dispute (Boltanski \& Thévenot, 2000, 2006; Gladarev \& Lonkila, 2013).

Based on these shared assumptions, to propose a discussion of the intersection between the theories of justification and stakeholders, a brief description of each theory follows.

\section{What are the main assumptions of ST?}

Freeman realized that the business environment became more dynamic, complex, requiring increasingly faster responses, and thus, the managers were being bombarded with changes and turbulence of the environment that until then were unprecedented. Thus, he proposed an approach that has an application in the real world and that focuses on the influence that stakeholders - groups or individuals that can affect or be affected by the achievement of an organizational goal - exert in the formulation of organizational strategy (Freeman, 2010b).

Its core premise is to provide better responses to those (dynamic and complex) demands, and managers need to consider stakeholders when making strategic decisions, in more detail on how to identify them, analyze them and negotiate with them (Freeman, 2010b). Stakeholders' interests have intrinsic value, which means that each group must be taken into account in management practices (Donaldson \& Preston, 1995; Harrison et al., 2015).

Previous literature classifies stakeholders in diverse ways. Freeman (2010) for instance, differentiates internal (owners, customers, employees and suppliers) from external stakeholders (governments, competitors, groups that advocate for consumer rights, environmentalists, and the media). Clarkson (1995), in turn, classify them as primary (those that directly impact the survival of the organization, such as shareholders, investors, employees, customers, and suppliers) and secondary (those that are engaged with the organization but do not directly influence its survival) stakeholders. When discussing the selected studies to illustrate our proposal, we highlight the involved stakeholders in each case.

The ST argues that businesses are not separate from society, and therefore managers are responsible for " [...] managing claims and lessening harms within an intricate network of social relationships" (Wood et al., 2018, p. 2). There is no stakeholder like the other, but their interests - which are often conflicting - can and should be aligned with the strategies of the organization, which may lead, (in)directly, to better performance (Crane, 2020; Donaldson \& Preston, 1995; Harrison et al., 2015). Hence, the organization should create value for its stakeholders without resourcing to tradeoffs, envisioning a sustainable relationship with its stakeholders, by attempting to satisfy several stakeholders' demands simultaneously without compromising the organizational interests (Crane, 2020; Donaldson \& Preston, 1995; Mascena \& Stocker, 2020; Phillips et al., 2019; Stocker \& de Mascena, 2019; Sulkowski et al., 2018).

Creating value for stakeholders includes both economic (i.e. profits) and non-economic benefits. For instance, an employee may seek psychological benefits such as recognition, satisfaction and/or learning (Argandoña, 2011). In our paper, when we discuss value regarding ST, it has the following meaning: i) either we are talking about the intrinsic value that stakeholders have, meaning that their interests must be accounted for by the organization, or ii) we are talking about an (economic and/or non-economic) benefit/gain that resulted from a situation of dispute and that encouraged or facilitated sustainable relationships among the parties involved". 
Different approaches address how managers can identify and prioritize stakeholders in a given situation - stakeholder salience (see Crane, 2020; Driscoll \& Starik, 2004; Magness, 2008; Mitchell et al., 1997; Schneider \& Sachs, 2017; Wood et al., 2018). However, tools for accurately account for stakeholders' interests remain obscure. We propose a model that aims to help managers - when interpreting their justifications- to identify, analyze and align the interests of these stakeholder groups with those of the organization so that the company has better performance (Crane, 2020; Freeman, 2010b; Harrison et al., 2015; Mitchell et al., 1997).

ST is applied in other fields of study such as marketing and finance. One of its primary uses, and which is adopted for this study, occurs in strategic management, whose main contribution can be summarized in the enrichment of the understanding of the strategies and behaviors adopted by organizations when considering the importance and influence that stakeholders exert on the formulation and implementation of the strategy (Barney \& Harrison, 2020; Harrison et al., 2015; Parmar et al., 2010).

Besides, ST has three aspects: descriptive (when used to describe corporate behavior), instrumental (when used as a tool to analyze the alignment among actors and its influence on the achievement of goals), and normative (when used to analyze corporate behavior in light of moral guidelines) (Donaldson \& Preston, 1995).

Stakeholder theory has benefitted from having contributions from other fields of knowledge such as sociology (Harrison et al., 2015; Phillips et al., 2019). Based on such aspects, it is possible to draw an insight from the interplay with JT in the following way: the descriptive feature of ST would benefit from JT, once it can be used to provide better, in-depth descriptions of cases, the instrumental, from analysis of justifications employed in situations of dispute and its impact on the (non) achievement of goals, and lastly, the normative, by the interpretation of moral principles that emerge from management practices.

In summary, the central points of ST can be listed as follows: i) there are stakeholders who influence and are influenced by the objectives of the organization; ii) managers need to take into account the effects of the interests and actions of stakeholders, as well as their context, to be successful; iii) for this relationship with stakeholders to be better understood, the theory recommends attitudes and practices that advocate for the moral responsibility of managers; iv) this new information can be applied in new structures and processes, as well as in the very formation of the strategy planning; and v) such actions may lead indirectly to better performance (Donaldson \& Preston, 1995; Godfrey \& Lewis, 2019; Harrison et al., 2015).

ST approaches several interactions among different groups which is based on the principles of trust, reciprocity, and fairness (Crane, 2020) and that it provides means by which ethics may be employed in a business context (Argandoña, 1998; Barney \& Harrison, 2020; Fontrodona, Ricart \& Berrone, 2018; Parmar et al., 2010; Phillips, Freeman \& Wicks, 2003). The JT framework is based on the premise of the inclusion of moral values within sociological studies by arguing that agreement is reached when justice among different parties is observed (Boltanski \& Thévenot, 2006).

Previous literature has found that stakeholders' perception of justice within management practices are linked to reciprocity, and thus enables sustainable relationships among parties, and has performance implications (Bosse \& Coughlan, 2016; Bosse, Phillips \& Harrison, 2009; Bridoux \& Stoelhorst, 2014; Bridoux \& Vishwanathan, 2020; Bundy, Vogel \& Zachary, 2018; Harrison, Bosse \& Phillips, 2010; Schneider \& Sachs, 2017). Furthermore, an interplay with sociology demonstrates that “ [...] people tend to accept the beliefs of people who are personally known and trust, people who are trusted by those other, and people in positions of great authority" (Wood et al., 2018, p. 38). Thence, trust and fairness provide conditions for reciprocity in managing multi expectations and enable sustainable relations among different parties, affecting organizational performance.

Therefore, there is a common ground between ST and JT (see Box 2) since both address debates on social reality anchored on moral principles (Barney \& Harrison, 2020; Gladarev \& Lonkila, 2013; Phillips et al., 2003), both emphasize the human agency towards promoting cooperation/situations of agreement reflecting a higher common principle/higher common consciousness about organization's impacts on society (Argandoña, 1998; Barney \& Harrison, 2020; Cloutier, Gond \& Leca, 2017; Thévenot, 2019).

We turn to the analysis of justifications, because "[...] language is taken by other persons as an indicator of future actions" (Mills, 1940, p. 940). Thus, by combining both theories, we provide tools for managers to accurately perceive who are their stakeholders, to assess their salience and interpret their interests in a given situation. 


\section{What are the main assumptions of JT?}

The justification theory framework analyzes situations of disagreement wherein justifications are employed to reach an agreement/outcome in non-violent and legitimate ways, among different actors (Boltanski \& Thévenot, 2006). It aims to put forward a model that provides methods for analyzing people's behaviors, particularly discourses and actions in situations of dispute (Boltanski \& Thévenot, 2000, 2006; Dequech, 2008; Eranti, 2018; Mills, 1940).

Justifications are "act of providing reasons for validity, legitimacy, and defensibility of an action, a belief or a social arrangement." (Susen, 2017, p. 350). The reasons that motivate the employment of justifications connect the actions of actors are bound to a given situation, to a specific context, and resort to norms, herein, principles of justice and the common good, to establish an outcome (Mills, 1940). Thus, justifications must be recognizable by others and are mainly employed when critical capacities are demanded, especially when disputes arise (Eranti, 2018).

Since organizations are composed of individuals, this model may also be used for the analysis of organizational management practices, since "the study of organizations arguably is, in its essence, the study of coordination" (Cloutier et al., 2017, p. 6). It is grounded in studying how organizations and businesses function in order to further a particular point of view into a generalizable "common good" (Boltanski \& Thévenot, 2006; Eranti, 2018; Thévenot et al., 2000).

Agreement and/or end of a dispute is reached by evoking justifications grounded on higher common principles. These principles relate to the ideals of justice and the common good, superior to individuals and that enables concordances between them. Those forms of the common good are called worths, and they are used to evaluated greater or lesser capacity to attribute value to these situations by individuals. Situations of agreement and disagreement are not static; they are dynamic and alternate. Sometimes there are situations of group acquiescence, sometimes of non-conformity (Boltanski \& Thévenot, 2006).

Interactions between actors require the use of justifications to coordinate actions in non-violent ways in social life. The "common good" principles are the tool that enables coordination in social life. Actors engage in public spaces to negotiate and/or defend socially accepted definitions of "the common good" (Patriotta et al., 2011). Thus, reaching an agreement or a compromise is a dynamic process in which often competing rationales are continuously (re)evaluated (Boltanski \& Thévenot, 2000).

An essential contribution of Boltanski and Thévenot's work to this essay is the mapping and categorization of seven orders of worth, which are differentiated by a single principle of value based on legitimate forms of the common good. Each sphere has different types of judgment and actions that are ranked according to their value. Value is a feature that assesses the qualification of beings in situations of dispute. Seeking for legitimate, i.e. non-violent, ways to reach an outcome requires that qualified beings engage in fair negotiations. Each order of worth has its higher common principle that values the qualification of involved beings. Such worlds emerged from ethnographic fieldwork and interviews, compared with historical and canonical philosophical classics (Eranti, 2018).

In order to live between these worlds, individuals and organizations must use justifications. Each world is defined by characteristics regarding the higher common principle, subjects, and objects of value, value relations, tests, forms of evidence, and failures (Boltanski \& Thévenot, 2000, 2006; Gladarev \& Lonkila, 2013; Thévenot et al., 2000). Each world manifests itself after the occurrence of disruptive moments and presents the subsequent attributes.

The inspired world is unstable and fragile, in which inspiration is motivated by deep emotions whose main subjects are the visionaries, in which moments of tests such as adventures or trips can produce uncertain paths that can culminate in the failure evidenced by individuals when they lose their originality and "return to the earth" (Boltanski \& Thévenot, 2006).

The domestic world is based on tradition and hierarchy, in which the hierarchically superior individuals have more value than the subordinates. Whose analogy that most resemble this world is the family led by patriarchal figures, observing rules of good manners, honor, and respect, in which the moments of peaks are the family ceremonies as marriages and, finally, their failures are shown when individuals become indiscreet, rude or treacherous (Boltanski \& Thévenot, 2006). 
Then the world of fame, according to Boltanski and Thévenot (2006), is defined by public opinion, in which the individuals with greater value require recognition made publicly, by the media, whose testing moments comprise the moments when individuals are immersed in their public roles and whose failures occur when they lose their image and fall into obscurity.

The civic world is based on collectivity and the common good in which laws and rights unify individuals and are better represented in democracies and republics, whose peak moments are expressed in situations that involve the collective will around a just cause in assemblies, congresses, and meetings, in which voting plays an important role. Its flaws are pointed out when the collectivity is fragmented, when elections are invalidated or when individual interests or inspirations stand out (Boltanski \& Thévenot, 2006).

Featured by competition and rivalry, the market world attributes more significant value to those who are winners and who have greater wealth. Moments of testing occur when there is a mercantile exchange whose failures are associated with financial losses, poverty, and slavery to money. In turn, the industrial world is defined by science and technology where the main attributes that give value to the individual are efficiency, productivity, and reliability. Labor is, therefore, a natural condition and investments involve commitments related to development. Its main moments of testing occur when performances are measured and its failures are presented when there is the objectification of people, seen as instruments for an end (Boltanski \& Thévenot, 2006).

The green world is related to environmental arguments. This world focuses on principles concerning harmony with nature, considering that environmental-friendly actions are related to the general good of humankind and its development. Generally, this world is used in combination with one of the other six and it addresses clean or non-polluting, renewable, recyclable sustainable issues. A distinct feature is that the green world is bounded with time and space concerns since it directly mentions problems that future generations might face (Giulianotti \& Langseth, 2016; Thévenot et al., 2000).

In situations of dispute, it is not possible only to select one world since in reality the worlds are situated in dynamic interactions. Such dynamic ways of dealing with different orders of justification in a situation are majorly classified as compromising and relativizing. Both forms comprehend types of avoidance of tests, wherein the former occurs due to the participants' will to reconcile a higher common principle and the latter due to the concordance by the ones involved that nothing matters and thus, evading disagreements (Boltanski \& Thévenot, 2006).

Combining both theories makes it is possible to compare different stakeholder groups while accounting for the particularities from a given context. An interplay with Justification theory enables the analysis of what regimes of justification were mainly employed, indicating what were the prioritized stakeholders, practices and values.

Considering both assumptions of ST and JT, in the next section, we discuss how environmental debates can benefit from our proposal by portraying previous studies to illustrate the feasibility of intersecting the ST and JT within the field of stakeholder-related research. We selected a theme related to environmental debates; nonetheless, other themes can also benefit from our proposal as discussed in the future research development section.

\section{Environmental debates: An intersection applicability}

Amidst debates on ST perspectives, there are debates on the importance of the natural environment for stakeholders, and, organizations. Both the organization and its stakeholders depend on the natural environment for existence and survival (Freeman et al., 2010; Hörisch \& Schaltegger, 2019). Regardless of the type of organization, all are dependent on natural resources. Thus, debates on business sustainability are fruitful and have been increasing in the literature (Hörisch \& Schaltegger, 2019).

Hörisch and Schaltegger (2019) approach this discussion and we build on their insights to strengthen our argument. When considering the natural environment on ST debates, two approaches are emphasized: i) it may be considered as an additional stakeholder or, ii) it may be considered as a shared concern among stakeholders. The former describes the natural environment as one of the stakeholders by itself since it abides by Freeman's (2010) definition; the natural environment is affected and influences organizational decisions and actions. Some authors claim that it should consider as the most important stakeholder 
of an organization (Driscoll \& Starik, 2004). The latter regards a perspective wherein the natural environment does not meet the human agency criteria embedded in Freeman's (2010) definition. Nonetheless, it must be considered as a primary concern amongst organizations and stakeholders. This essay adheres to this perception.

Regardless of the adopted perception, there are benefits of including the natural environment in ST debates since both are related to environmental improvement applying the ST principle of not resorting to tradeoffs. In other words, stakeholders influence sustainability measures and may promote solutions to environmental problems.

Furthermore, environmental debates may be positively enhanced by transdisciplinary approaches (Hörisch \& Schaltegger, 2019). Meanwhile, the JT advocates that beings, hereof, stakeholders, and the natural environment, in situations of dispute, governed by the observance of a higher common principle, herein, sustainability, employ justifications in negotiations to reach a situation of agreement (Boltanski \& Thévenot, 2006). Therefore, JT is also an appliable framework to analyze environmental issues.

We selected three studies on environmental debates to shed some light on different possibilities of applying our proposed intersection.

\section{Justification theory in socio-cultural analysis of the value of fish and fisheries: a case of Baltic salmon}

The study of Ignatious and Haapasaari (2018) used the JT in order to identify the socio-cultural values related to the case study of Baltic salmon providing a discussion with the governance and management of fisheries. The resources coming from the fishery have different meanings for society, in which the observation of the divergent values of the common good is analyzed.

The common good can be seen in different ways by stakeholders, which leads to problems of governance legitimacy. The authors then, analyze discourses and actions that have been adopted in the situation by the governors, commercial and recreational fishers, environmental NGOs, researchers, residents, and rivers (Ignatius \& Haapasaari, 2018).

The two main premises of this study are the following: the values are contextualized both in the management decision-making process and in the governance procedures, since they are influenced by the world view of the stakeholders involved in these processes and, governance systems occur from the enactment viewpoint since there is an interdependence between the actors and the structures created by them (Ignatius \& Haapasaari, 2018).

Links are established between ST and JT when highlighting that the specific knowledge about the values that stakeholders' hold and incorporate in the decision-making processes is of extreme importance. Such knowledge results in the way of strengthening managerial practices such as, for example, negotiation of objectives and provides decisions executed in more satisfactory and sustainable - ways. However, identifying and analyzing these values is a challenge for managers and researchers alike (Ignatius \& Haapasaari, 2018).

Its analysis applies seven worlds of value. The green world was included because it was intertwined with the behaviors of the stakeholders involved. In summary, the worlds were configured as follows regarding the Baltic salmon: i) the civic world was related to the centrality of fair management practices, ii) the green world was seen as the bearer of various ecological values, iii) the domestic world represented as a part of the Nordic heritage and also as a work tradition related to fishing, iv) the world of inspiration was characterized by emotional attachments and recreational importance, v) the world of fame, in which salmon has symbolic importance for stakeholders, vi) the world of the market that refers to the economic value of salmon and, vii) the industrial world whose focus is the decrease in importance regarding production resources (Ignatius \& Haapasaari, 2018).

They conclude that the understanding of the reasons for the importance and values of fishing for different stakeholders contributed to the formulation of decisions to which the stakeholders could agree. JT highlights the power of good arguments rather than the influence exerted by essential figures. At the same time, it causes stakeholders to analyze what is most beneficial for all and adapt their interests by observing the common good, which in turn gives legitimacy and greater acceptability to their actions, promoting sustainable governance practices (Ignatius \& Haapasaari, 2018). 


\section{Maintaining legitimacy: controversies, orders of worth and public justifications}

Centered in the case study of the nuclear accident that occurred in Germany involving the Swedish company Vattenfall, Patriotta et al. (2011) use JT to analyze how different stakeholders act through public speeches to maintain the legitimacy of institutions that are relevant to their interests.

Public documents are analyzed, mainly those related to the coverage that was made by the media. Because the discourses of justifications occurred in the public arena, the media plays a central role in our society. The media is considered as one of the stakeholders analyzed. Other stakeholders involved in the dispute were: the company Vattenfall, political agents, NGOs, and citizens.

The authors then describe how the movement of value order discourses occurred and was modified during the controversy. Debates of economic, political, social, and cultural origin emerged during the process and were analyzed differently, by observing the types of worlds that stood out. They demonstrated how, during a public dispute, stakeholders might employ the same order of worth to justify either a position or its opposite, thus guiding public debate based on their interests (Patriotta et al., 2011).

In short, justifications from the industrial world - related to technological and scientific arguments - were used to defend the company regarding this episode - in detriment of political and social aspects. During the discord groups of stakeholders were identified in favor and against the use of nuclear energy that modified their discourses according to the situation, always aiming to make their positions more relevant in social terms, seeking to argue for an alignment with principles of the common good (Patriotta et al., 2011).

Therefore, by mobilizing higher-order principles, stakeholders were able to reach an outcome and maintain the legitimacy of its company and as the use of nuclear power. Power and legitimacy asymmetries played a major role in this episode, in which more powerful stakeholders were able to be "louder" than others when claiming its legitimacy (Patriotta et al., 2011).

\section{Justification regimes: conflicting arguments and the construction of legitimacy in nature conservation practices in the Netherlands}

This study evaluated environmental conservation practices in the Netherlands through arguments that legitimated or invalidated them. This study sheds light on the aspect that in environmental issues, the issue is not only the inclusion of stakeholder participation but also a construction of validity of the arguments used to demonstrate their level of real participation, as well as the results obtained in the process (Arts et al., 2018).

To this end, two regions were chosen for analysis. These were places in which the community was engaged in organized protests against the implementation of conservation plans led by conservation organizations. The unit of analysis focused on contestations and negotiations of the involved stakeholders (Arts et al., 2018).

The particularities of this work can be simplified as follows: i) in both cases, critical actors became recognized as relevant stakeholders, thus actively participating in the discussions; ii) of the worlds used in the justification speeches, four stood out: the domestic, the industrial, the inspirational and the green; from the two remaining worlds, the civic was not used explicitly, but their attributes were implicit for everyone, and the market was rarely used because their arguments were seen as invalid in the discussions that occurred and also for the legitimacy of stakeholders and, iii) there was an asymmetry of influence and participation between the groups of stakeholders, in which the arguments that were based on technical efficiency and emotional issues and inspiration were not sufficiently versatile at times of rapprochement when the principle of the common good was at stake (Arts et al., 2018).

Stakeholders, local communities (residents), nature conservation organizations and government agencies, were unwilling to shift between justifications to reach a compromise. Besides, some justifications - related to the inspired world - were de-legitimized. Such insight indicates that there may also be a hierarchy of importance (legitimacy) of the orders of worth in a given situation. The effectiveness of the reached outcome depends on the legitimacy of justifications employed by stakeholders (Arts et al., 2018). 


\section{Synthesis: how do previous case studies shed light on the intersection between ST and JT?}

First, the possibilities of applying our proposal are not limited to environment-related situations, even though the three articles described in this study are related to environmental issues. Nonetheless, they allow us to pinpoint the interweaving between ST and JT.

Second, our proposal can be methodologically applied as the following: i) in the choice for a case study or multiple case studies, ii) in the listing of stakeholders that shall be used within the study and, iii) in the encoding of each stakeholder's justifications grounded on the analysis of the orders of worth. Moreover, our proposal encourages analysis on organizational or group level, once the justifications to be analyzed concerns groups or organizations' positioning in a given dispute situation. Box 1 synthesizes the central topics of the three studies.

Third, the JT framework allows the investigation of competing orders of worth employed by distinct actors, herein named as stakeholders, within the organization's reality. These articles demonstrate viable research applications investigating a plurality of controversies among different stakeholder groups and types of organizations. In other words, how these groups negotiated and prioritized orders of worth to reach an agreement or a compromise between the parties involved.

Forth, the analysis and conclusions of the three articles differ and present possibilities as replicating models for future research, especially regarding situations of public debates whereon practices are questioned and actors engage in negotiations on courses of action trying to reach agreements (Giulianotti \& Langseth, 2016; Gladarev \& Lonkila, 2013; Jagd, 2011; Ylä-Anttila \& Luhtakallio, 2016).

\section{Box 1}

Synthesis of the three analyzed studies

\begin{tabular}{|c|c|c|c|}
\hline & Ignatius and Haapasaari (2018) & $\begin{array}{l}\text { Patriotta et al. } \\
\qquad(2011)\end{array}$ & $\begin{array}{l}\text { Arts et al. } \\
\text { (2018) }\end{array}$ \\
\hline Object of study & Baltic Salmon. & Nuclear accident in Germany. & Dutch nature conservation practices. \\
\hline $\begin{array}{l}\text { Public debates } \\
\text { on }\end{array}$ & Fishery governance practices. & The legitimacy of nuclear power. & $\begin{array}{l}\text { Governance and public participation } \\
\text { regarding environmental practices. }\end{array}$ \\
\hline Mair & $\begin{array}{l}\text { To apply the JT to analyze the } \\
\text { ways stakeholders prioritize } \\
\text { fish resources and how political } \\
\text { decisions influence disputes } \\
\text { concerning fisheries management. }\end{array}$ & $\begin{array}{l}\text { To apply JT to analyze the ways } \\
\text { different stakeholders engage with } \\
\text { discourses and objects to maintain } \\
\text { the legitimacy of institutions that } \\
\text { are relevant to their activity. }\end{array}$ & $\begin{array}{l}\text { To apply JT to analyze the dynamics } \\
\text { in justifications used to legitimize and } \\
\text { de-legitimize Dutch nature conservation } \\
\text { practices. }\end{array}$ \\
\hline How ST is used & $\begin{array}{l}\text { Enables to identify stakeholder } \\
\text { groups and to analyze their } \\
\text { prioritized values. }\end{array}$ & $\begin{array}{l}\text { Enables to identify stakeholder, } \\
\text { their interests and the institutions } \\
\text { they represent. }\end{array}$ & $\begin{array}{l}\text { Enables to identify relevant actors involved } \\
\text { in the disputes. }\end{array}$ \\
\hline $\begin{array}{l}\text { Primary and } \\
\text { Secondary } \\
\text { stakeholders }\end{array}$ & $\begin{array}{l}\text { Governors, commercial and } \\
\text { recreational fishers, environmental } \\
\text { NGOs, researchers, residents, and } \\
\text { rivers. }\end{array}$ & $\begin{array}{l}\text { The media, the company Vattenfall, } \\
\text { political agents, NGOs and citizens. }\end{array}$ & $\begin{array}{l}\text { Local communities (residents), nature } \\
\text { conservation organizations and government } \\
\text { agencies. }\end{array}$ \\
\hline $\begin{array}{l}\text { How JT } \\
\text { is used }\end{array}$ & $\begin{array}{l}\text { Enables to identify socio-cultural } \\
\text { values converging to the common } \\
\text { good. }\end{array}$ & $\begin{array}{l}\text { Enables to analyze how stakeholder s } \\
\text { engage, handle disputes and maintain } \\
\text { the legitimacy of their institutions. }\end{array}$ & $\begin{array}{l}\text { Enables the analysis of the construction } \\
\text { of legitimacy. } \\
\text { Four worlds were prioritized: green, } \\
\text { domestic, industrial and inspired. }\end{array}$ \\
\hline $\begin{array}{l}\text { Method } \\
\text { applied }\end{array}$ & $\begin{array}{l}\text { Justification analysis of secondary } \\
\text { data: articles, book chapters and } \\
\text { research reports. }\end{array}$ & $\begin{array}{l}\text { Content analysis of secondary data: } \\
\text { Vattenfall official documents and } \\
\text { reports and newspaper reports. }\end{array}$ & $\begin{array}{l}\text { In-depth semi-structured interviews. } \\
\text { Informal conversations. } \\
\text { Triangulation: analysis of documents from } \\
\text { several sources and the media. }\end{array}$ \\
\hline $\begin{array}{l}\text { Findings - } \\
\text { theoretical \& } \\
\text { managerial }\end{array}$ & $\begin{array}{l}\text { Power differences among } \\
\text { stakeholders are mitigated when each } \\
\text { actor needs to provide legitimate } \\
\text { justifications that address the } \\
\text { common good. }\end{array}$ & $\begin{array}{l}\text { Justifications' effectiveness depends } \\
\text { on the stakeholders' ability to } \\
\text { provide conformity between their } \\
\text { arguments with common higher- } \\
\text { order principles. }\end{array}$ & $\begin{array}{l}\text { Incompatibility between the inspired and } \\
\text { industrial worlds. } \\
\text { Discrepancy between the invitation of } \\
\text { new actors to the negotiation table and } \\
\text { observance of dismissal of their arguments. }\end{array}$ \\
\hline
\end{tabular}

Source: Elaborated by the authors. 
For instance, it would be interesting to replicate Patriotta et al.'s (2011) study in other nuclear and radiation accidents in less developed countries to compare how stakeholders justify nuclear power's legitimacy in different cultures. The same applies to the other two studies. It would be intriguing to compare how organizations provide justifications to maintain their legitimacy in cases of environmental accidents or disasters (e.g., oil spill, soil or air contamination) in different parts of the world to analyze whether they are similar or not.

Furthermore, it is important to emphasize that orders of worth are dispute-bounded. Therefore, justifications related to one world are dynamic and shift in a given situation. In sum, these studies also illustrate that - similarly to ST - the JT framework highlights the descriptive, instrumental, and normative pillars for analyzing the organization-stakeholder relationship (see Donaldson \& Preston, 1995). To substantiate the proposed intersection, Box 2 summarizes a comparison of fundamental concepts of both theories.

Box 2

ST and JT intersections

\begin{tabular}{|c|c|c|}
\hline Topics & Stakeholder Theory & Justification Theory \\
\hline $\begin{array}{l}\text { Central theoretical } \\
\text { foundations } \\
\text { (selected sample) }\end{array}$ & $\begin{array}{l}\text { - Freeman (1984). } \\
\text { - Freeman et al. (2020). } \\
\text { - Donaldson and Preston (1995). } \\
\text { - Mitchell et al. (1997). }\end{array}$ & $\begin{array}{l}\text { - Boltanski and Thévenot (2006). } \\
\text { - Lafaye, Moody and Thévenot (2000). }\end{array}$ \\
\hline $\begin{array}{l}\text { Central theoretical } \\
\text { questions }\end{array}$ & $\begin{array}{l}\text {-What is the relationship between the organization } \\
\text { and its external environment? } \\
\text { - What is the organization's behavior towards its } \\
\text { external environment? }\end{array}$ & $\begin{array}{l}\text { - How can actors reach an agreement, given the existence } \\
\text { of multiple representations of the common world? } \\
\text { - What worlds do actors draw upon to express their } \\
\text { disagreement and to justify their perspective? }\end{array}$ \\
\hline Premisses & $\begin{array}{l}\text { - Pluralism: Multiple interests are observed in } \\
\text { organizational reality. }\end{array}$ & $\begin{array}{l}\text { - Pluralism: multiples worlds coexist in the form of } \\
\text { arrangements and compromises. }\end{array}$ \\
\hline $\begin{array}{l}\text { Agency and mindset } \\
\text { of beings }\end{array}$ & $\begin{array}{l}\text { - Actors mobilize social cognitive competences. } \\
\text { - Moral and ethical groundings make it possible } \\
\text { to achieve beneficial outcomes for both the } \\
\text { organization and its stakeholders. }\end{array}$ & $\begin{array}{l}\text { - Actors mobilize social cognitive competences. } \\
\text { - Common humanity makes it possible to a sincere search } \\
\text { of agreements for the common good (Moral dimension). }\end{array}$ \\
\hline $\begin{array}{l}\text { Stakeholder } \\
\text { salience }\end{array}$ & $\begin{array}{l}\text { - Some stakeholders have more power and } \\
\text { legitimacy than others and may, therefore, have } \\
\text { more "voice" and be more influential regarding } \\
\text { decision and action outcomes. }\end{array}$ & $\begin{array}{l}\text { - Assumptions and values toward the common good } \\
\text { (orders of worth) may vary among stakeholders. } \\
\text { - In the search of agreement, some orders of worth may } \\
\text { prevail against others. }\end{array}$ \\
\hline Dispute & $\begin{array}{l}\text { - Disputes arise and are negotiated since many } \\
\text { actors are involved, and thus many divergent } \\
\text { interests compete for attention. } \\
\text { - The goal: reaching a solution without resourcing } \\
\text { to tradeoffs. }\end{array}$ & $\begin{array}{l}\text { - Disputes result in the confrontation of different orders } \\
\text { of worth in the context of disputes since beings evaluate } \\
\text { things and justify a perspective in public disputes. } \\
\text { - It may be resolved through a test (evaluating the worth } \\
\text { of a situation, a being, or an object), or a compromise } \\
\text { (new arrangement combining multiple worlds). }\end{array}$ \\
\hline
\end{tabular}

Source: Elaborated by the authors.

Box 2 features core topics of ST and JT by sketching a comparison between theoretical foundations and questions as well as premises, understandings on agency and mindset of beings, stakeholder salience, and disputes may elucidate connections whereby ST and JT may dialogue.

For instance, i) both ground their studies in pluralistic premises, in which the social reality is enacted by multiple actors and interests, ii) both recognize an active role of actors, ie, their cognitive competence to engage in criticism when dealing with situations of dispute, in which for both theories, based on moral principles actors seek a beneficial outcome of the situation, both acknowledge asymmetry regarding actors' interests and actions and iii) both share similar discernment regarding situations of dispute that emerge from pluralistic contexts.

Subsequently, we discuss why our proposal is relevant, by exploring the expected theoretical and practical contributions, while accounting for its limitations and proposing future research developments. 


\section{CONCLUDING REMARKS: WHY SUCH AN INTERDISCIPLINARY INTERSECTION IS RELEVANT AND WHAT DO WE EXPECT TO ACHIEVE BY PROPOSING IT?}

The idea of this essay arose after reading the seminal texts of the ST carried out by Freeman, as a possibility of deepening the explanatory scope of the theory. Reflecting upon a theoretical interplay, enabled us to provide an alternative way of imposing some order and to make some sense of managers' challenge to identify and engage with their stakeholders (Suddaby, 2014). The theoretical research paper design was specifically chosen since it is an approach particularly useful to broaden interdisciplinary discussions by encouraging future developments (Bertero, 2011; Meneghetti, 2011). The JT should be used to understand how stakeholders engage in public debates in order to manage disagreement while maintaining their legitimacy of the institutions of which they are part (Patriotta et al., 2011).

The purpose of this essay is to present an alternative approach to help managers (and scholars) - by interpreting their justifications - to identify, analyze and align the interests of these stakeholder groups with those of the organization so that the company has better performance (Crane, 2020; Freeman, 2010b; Harrison et al., 2015; Mitchell et al., 1997; Schneider \& Sachs, 2017).

Our proposal can be applied to understand disputes, i.e., public debates on an issue or controversies, that emerge from social reality. Such situations must be embedded in uncertain and complex contexts, wherein the analysis of justifications shed light on the stakeholders and contribute to the interpretation of their interests in a given situation. We argue that the alignment of interests is beneficial in a dispute and promotes sustainable relationships among the parties involved, influencing organizational performance (Crane, 2020; Ignatius \& Haapasaari, 2018).

\section{Implications for theory}

Research on interactions with stakeholders has been blossoming due to the increasing interdependence between business and society (Mascena \& Stocker, 2020). To date, previous literature on stakeholder salience and engagement has dealt with issues regarding power, legitimacy and urgency (Magness, 2008; Mitchell et al., 1997; Wood et al., 2018), organization-stakeholders fit and engagement with stakeholders for value creation (Bundy et al., 2018; Kimiagari et al., 2013; Sulkowski et al., 2018). Finding common ground with the Justification theory facilitates the study of uncertain and complex disputes involving the interaction among organization-stakeholders by scholars.

Our essay answers to claims for reflection on how managers coordinate and engage with stakeholders with often competing values and needs, especially in situations of dispute (Bundy et al., 2018).

In order to show how the two theories can be used together, we developed a set of propositions that arise from our previous discussion on the intersection between JT and ST and could inspire future works and theoretical developments.

First, based on the fundaments of JT, we propose the following proposition that could apply to understand stakeholder behavior in the context of a dispute, such as those described in the analyzed cases.

Proposition 1 In a public dispute, stakeholders are likely to justify their positions and arguments based on the orders of worth they prioritize. Those orders of worth are presented as a means for achieving the common good.

Furthermore, as shown by Patriotta et al. (2011), to increase the effectiveness of justifications, i.e., to allow the achievement of goals, stakeholders attempt to align their interests with the common good. Thus, we propose:

Proposition $\mathbf{2}$ In a public dispute, stakeholders' justifications are likely to achieve greater effectiveness when they are perceived as consonant with higher common principles.

In addition, it should be noted that orders of worth are not static or immutable. They may change while the dispute advances and they are contextually-bound Hence, power asymmetries may influence the prioritization of orders of worth. Thus, it would also be fruitful to apply our proposal to analyze the impacts of power asymmetries and legitimacy tests in controversies (Arts et al., 2018; Patriotta et al, 2011). This leads to propositions 3 and 4: 
Proposition $\mathbf{3}$ In a public dispute, powerful organizations and/or stakeholders employ justifications attempting to defend its legitimacy and may be held as more important or the only one that is legitimate in a controversy.

Proposition 4 In a public dispute, less powerful organizations and/or stakeholders employ justifications attempting to undermine its opponent's legitimacy and may be held as less important or non-legitimate in a controversy.

Moreover, there are situations that in spite of the parties involved having different levels of power and influence capacity, stakeholders and organizations can reach an agreement built on the negotiation of interests. As it was evident in Ignatius and Haapasaari's (2018) study, when actors employ justifications in consonance with higher common good principles and mitigating power asymmetries, the outcome of the negotiations has greater acceptability and promotes sustainable governance practices. This leads to propositions 5 and 6 :

Proposition $\mathbf{5}$ In a given situation, power asymmetry may be disregarded among the parties involved and justifications may be employed to evoke a common good.

Proposition 6 When an agreement is reached by observing the common good, addressing the stakeholders and organizations' interests, the outcome of a dispute is held as more acceptable and promotes sustainable relationships among organization-stakeholders.

Finally, our proposal argues for an alternative lens to assist managers' challenges regarding identifying and engaging with their stakeholders. By interpreting stakeholders' justifications managers can identify, analyze, and align the interests of these stakeholder groups with those of the organization. This theme leads to our final proposition:

Proposition $\mathbf{7}$ In a public controversy, by assessing the justifications that emerge, managers can identify stakeholders, interpret their interests and thus, actively engage and negotiate with them.

Such a possible combination may happen in different ways to provide further and insightful explanations regarding organization phenomena by amplifying the power of explanation of ST since one of the most constructive developments in many of the academic disciplines was the call for works of an interdisciplinary nature. Disciplines have long been able to learn from each other and, of course, the concept of stakeholder is broad enough for collaborative efforts. A further contribution of such an intersection would be to augment moral debates in stakeholder-related research (Fontrodona et al., 2018; Harrison et al., 2015; Parmar et al., 2010).

JT has already been used in other areas of study such as public health, studies on responsibility, and critical studies. It is noteworthy to mention that such an intersection within stakeholder-related research has already been made in some European studies, strengthening the argument that advantages are arising from this dialogue (Jagd, 2011). In sum, answering the question of how can the JT complement the ST we observed that the intersections between ST and JT might unfold into the following possibilities:

To enrich the understanding of the normative and moral mechanisms involved in organization-stakeholder relationships, through the identification of prioritized orders of worth during situations of dispute;

To move forward from identifying stakeholder salience also to consider "worlds diversity", showing the interplay of power and legitimacy asymmetries within the negotiation of different worlds of value;

To provide an alternative framework to analyze cases of (re)construction of legitimacy during and after situations of dispute and thus,

To include the JT framework in stakeholder analysis, by practitioners and researchers which brings novel methodological possibilities.

Although we do not provide an exhaustive list of future applications, we hope that reflections arise from this discussion over the intersection of two theories and that it may foster future studies using such an insightful approach. 


\section{Implications and limitations in practice}

Our proposal has practical implications for managers - and stakeholders - attempting to establish sustainable relations with their stakeholders while creating value for both parts involved. Organizational survival and performance are dependent on the alignment between the organization and its stakeholders. Thus, managers must address multiple expectations and interests (Bundy et al., 2018).

By interpreting stakeholders' justifications, managers can assess the salience of claims in a given situation, to evaluate their interests and thus, to negotiate with them while seeking an alignment with all the involved parties. It has been already suggested in the literature that " [...] managers who want to foster positive relationships with stakeholders should concentrate on aligning their values and priorities [...]" (Bundy et al., 2018, p. 476). Our proposal illustrates a possible way to achieve such alignment. Also by interpreting justifications it is possible to foresee, to some extent, future decisions or actions related to specific issues (Mills, 1940; Schneider \& Sachs, 2017).

Although environmental issues demonstrated to be an insightful theme, our proposal is not limited to this topic; other issues related to public controversies are fruitful, such as misconduct, accidents, disasters (see Perkiss \& Moerman, 2020). Public debates or disputes are mandatory for the application of our proposal because when facing such context, stakeholders mandatorily engage in justifications.

Moreover, other limitations include the theoretical boundaries of the intersection between ST and JT. On the one hand, ST argues that organizations and stakeholders often have conflicting interests but must seek to align such interests. Such alignment may lead to better organizational performance (Barney \& Harrison, 2020; Crane, 2020; Freeman, 2004; Harrison et al., 2015). Hence, ST is elaborated on premises that consider power and legitimacy asymmetries among the involved parties. On the other hand, for JT, power and legitimacy asymmetries may play a role in dispute situations, but negotiation among the involved actors may mitigate such asymmetries depending on the situation, as it was evident in Ignatius and Haapasaari's (2018) findings. Future studies can test our propositions to further contribute to the herein proposed intersection. In social reality, especially in situations of dispute, actors engage in interactions by employing justifications in order to negotiate and bargain interests and thus reach an alignment/ coordination of activities (Thévenot, 2002).

We hope our proposal fosters future application insights on the understanding of pluralistic justifications observed in the organization-stakeholders relationship during public controversies.

\section{ACKNOWLEDGEMENTS}

We would like to thank the anonymous reviewers and participants from the EnANPAD 2020 for all their helpful comments during different stages of this paper. We acknowledge the support from Coordination for the Improvement of Higher Education Personnel (CAPES - Brazil) in the form of an MSc scholarship to Helna Almeida de Araujo Góes under the financing code 001. 


\section{REFERENCES}

Argandoña, A. (1998). The stakeholder theory and the common good. Journal of Business Ethics, 17(9-10), 1093-1102. Retrieved from https://doi.org/10.1023/A:1006075517423

Argandoña, A. (2011, May). Stakeholder theory and value creation (IESE Business School Working Paper No. 922). Barcelona, Spain: IESE Business School, University of Navarra.

Arts, I., Buijs, A. E., \& Verschoor, G. (2018). Regimes of justification: competing arguments and the construction of legitimacy in Dutch nature conservation practices. Journal of Environmental Planning and Management, 61(5-6), 1070-1084. Retrieved from http://dx.doi.org /10.1080/09640568.2017.1319346

Barney, J. B., \& Harrison, J. S. (2020). Stakeholder Theory at the Crossroads. Business and Society, 59(2), 203-212. Retrieved from https://doi.org/10.1177/0007650318796792

Bertero, C. O. (2011). Réplica 2 - o que é um ensaio teórico? Réplica a Francis Kanashiro Meneghetti. Revista de Administração Contemporânea, 15(2), 338-342.

Boltanski, L., \& Thevenot, L. (1999). The Sociology of Critical Capacity. European Journal of Social Theory, 2(3), 359-377.

Boltanski, L., \& Thévenot, L. (2000). The reality of moral expectations: A sociology of situated judgment. Philosophical Explorations: An International Journal for the Philosophy of Mind and Action, 3(3), 208231. Retrieved from https://doi.org/10.1080/13869790008523332

Boltanski, L., \& Thévenot, L. (2006). On Justification: Economies of Worth. Princeton, NJ: Princeton University Press.

Bosse, D. A., \& Coughlan, R. (2016). Stakeholder Relationship Bonds. Journal of Management Studies, 53(7), 1197-1222. Retrieved from https://doi.org/10.1111/joms.12182

Bosse, D. A., Phillips, R. A., \& Harrison, J. S. (2009). Research notes and commentaries stakeholders, reciprocity, and firm performance. Strategic Management Journal, 30(4), 447-456. Retrieved from https://doi.org/10.1002/smj.743

Bridoux, F. M., \& Stoelhorst, J. W. (2014). Microfoundations for stakeholder theory: Managing stakeholders with heterogeneous motives. Strategic Management Journal, 35(1), 107-125. Retrieved from https://doi.org/10.1002/smj.2089

Bridoux, F. M., \& Vishwanathan, P. (2020). When Do Powerful Stakeholders Give Managers the Latitude to Balance All Stakeholders' Interests? Business and Society, 59(2), 232-262. Retrieved from https://doi.org/10.1177/0007650318775077

Brondoni, S., Bosetti, L., \& Civera, C. (2020). Ouverture de 'CSR and Multi-Stakeholder Management.' Symphonya. Emerging Issues in Management, 1, 1-15. https://doi.org/10.4468/2019.1.01ouverture

Bundy, J., \& Pfarrer, M. D. (2015). A burden of responsibility: The role of social approval at the onset of a crisis. Academy of Management Review, 40(3), 345-369. Retrieved from https://doi.org/10.5465/ amr.2013.0027

Bundy, J., Vogel, R. M., \& Zachary, M. A. (2018). Organizationstakeholder fit: A dynamic theory of cooperation, compromise, and conflict between an organization and its stakeholders. Strategic
Management Journal, 39(2), 476-501. Retrieved from https://doi. org/10.1002/smj.2

Clarkson, M. B. E. (1995). A Stakeholder Framework for Analyzing and Evaluating Corporate Social Performance. Academy of Management Review, 20(1), 92-117.

Cloutier, C., Gond, J. P., \& Leca, B. (2017). Justification, evaluation and critique in the study of organizations: An introduction to the volume. In C. Cloutier, J. P. Gond \& B. Leca (Eds.), Justification, Evaluation and Critique in the Study of Organizations (Research in the Sociology of Organizations, Vol. 52, pp. 3-29). Bingley, UK: Emerald Publishing Limited. Retrieved from https://doi.org/10.1108/ S0733-558X20170000052001

Crane, B. (2020). Revisiting who, when, and why stakeholders matter: Trust and stakeholder connectedness. Business \& Society, 59(2), 263-286.

Daudigeos, T., Roulet, T., \& Valiorgue, B. (2020). How Scandals Act as Catalysts of Fringe Stakeholders' Contentious Actions Against Multinational Corporations. Business and Society, 59(3), 387-418. Retrieved from https://doi.org/10.1177/0007650318756982

Dequech, D. (2008). Logics of justification and logics of action. Journal of Economic Issues, 42(2), 527-535. Retrieved from https://doi.org/ 10.1080/00213624.2008.11507162

Donaldson, T. (2002). The Stakeholder Revolution and the Clarkson Principles. Business Ethics Quarterly, 12(2), 107-111. Retrieved from https://doi.org/10.5840/beq200212211

Donaldson, T., \& Preston, L. E. (1995). The stakeholder theory of the corporation. The Academy of Management Review, 20(1), 65-91. Retrieved from https://doi.org/10.5465/amr.1995.9503271992

Dorobantu, S. (2019). Sketches of New and Future Research on Stakeholder Management. In J. S. Harisson, J. B. Barney, R. E. Freeman, R. A. Phillips (Eds.), The Cambridge Handbook of Stakeholder Theory (pp. 256-263). Cambridge, UK: Cambridge University Press.

Driscoll, C., \& Starik, M. (2004). The primordial stakeholder: Advancing the conceptual consideration of stakeholder status for the natural environment. Journal of Business Ethics, 49, 55-73. Retrieved from https://doi.org/10.1023/B:BUSI.0000013852.62017.0e

Eranti, V. (2018). Engagements, grammars, and the public: From the liberal grammar to individual interests. European Journal of Cultural and Political Sociology, 5(1-2), 42-65. Retrieved from https://doi.org /10.1080/23254823.2018.1442733

Fontrodona, J., Ricart, J. E., \& Berrone, P. (2018). Ethical Challenges in Strategic Management: The 19th IESE International Symposium on Ethics, Business and Society. Journal of Business Ethics, 152(4), 887-898. Retrieved from https://doi.org/10.1007/s10551-018-3825-2

Freeman, R. E. (2004). The stakeholder approach revisited. Zeitschrift Für Wirtschafts- Und Unternehmensethik, 5(3), 228-241. Retrieved from https://doi.org/10.5771/1439-880x-2004-3-228

Freeman, R. E. (2010a). Managing for stakeholders: Trade-offs or value creation. Journal of Business Ethics, 96(1), 7-9. 
Freeman, R. E. (2010b). Strategic management: A stakeholder approach. Cambridge, UK: Cambridge University Press.

Freeman, R. E., Harrison, J. S., Wicks, A. C., Parmar, B. L., \& Colle, S. (2010). The Stakeholder Theory: The state of the art. Cambridge, UK: Cambridge University Press.

Freeman, R. E., Phillips, R., \& Sisodia, R. (2020). Tensions in Stakeholder Theory. Business and Society, 59(2), 213-231. Retrieved from https:// doi.org/10.1177/0007650318773750

Gioia, D. A., \& Chittipeddi, K. (1991). Sensemaking and Sensegiving in strategic change initiation. Strategic Management Journal, 12, 433-448.

Giulianotti, R., \& Langseth, T. (2016). Justifying the civic interest in sport: Boltanski and Thévenot, the six worlds of justification, and hosting the Olympic games. European Journal for Sport and Society, 13(2), 133-153.

Gladarev, B., \& Lonkila, M. (2013). Justifying Civic Activism in Russia and Finland. Journal of Civil Society, 9(4), 375-390. Retrieved from https://doi.org/10.1080/17448689.2013.844450

Godfrey, P. C., \& Lewis, B. (2019). Pragmatism and pluralism: A moral foundation for stakeholder theory in the twenty-first century. In J. S. Harrison, J. B. Barney, E. Freeman, \& R. A. Phillips (Eds.), The Cambridge Handbook of Stakeholder Theory (pp. 19-34). Cambridge, UK: Cambridge University Press. Retrieved from https:// doi.org/10.1017/9781108123495.002

Harrison, J. S., Bosse, D. A., \& Phillips, R. A. (2010). Managing for stakeholders, stakeholder utility functions, and competitive advantage. Strategic Management Journal, 31(1), 58-74. Retrieved from https:// doi.org/10.1002/smj.801

Harrison, J. S., Freeman, R. E., \& Abreu, M. C. S. (2015). Stakeholder theory as an ethical approach to effective management: Applying the theory to multiple contexts. Revista Brasileira de Gestao de Negocios, 17(55), 858-869. Retrieved from https://doi.org/10.7819/ rbgn.v17i55.2647

Hörisch, J., \& Schaltegger, S. (2019). Business, the Natural environment and sustainability: A Stakeholder Theory Perspective. In J. S. Harrison, J. B. Barney, E. Freeman, \& R. A. Phillips (Eds.), The Cambridge Handbook of Stakeholder Theory (pp. 132-143). Cambridge, UK: Cambridge University Press.

Ignatius, S., \& Haapasaari, P. (2018, February). Justification theory for the analysis of the socio-cultural value of fish and fisheries: The case of Baltic salmon. Marine Policy, 88, 167-173.

Isabella, L. A. (1990). Evolving Interpretations as a Change Unfolds : How Managers Construe Key Organizational Events. The Academy of Management Journal, 33(1), 7-41. Retrieved from https://doi. org/10.1177/1094428112452151

Jagd, S. (2011). Pragmatic sociology and competing orders of worth in organizations. European Journal of Social Theory, 14(3), 343-359. Retrieved from https://doi.org/10.1177/1368431011412349

Jensen, T., \& Sandström, J. (2011). Stakeholder theory and globalization: The challenges of power and responsibility. Organization Studies, 32(4), 473-488. Retrieved from https://doi.org/10.1177/0170840611400290

Kimiagari, S., Keivanpour, S., Mohiuddin, M., \& Van Horne, C. (2013). The Cooperation Complexity Rainbow: Challenges of Stakeholder Involvement in Managing Multinational Firms. International Journal of Business and Management, 8(22), 50-64. Retrieved from https:// doi.org/10.5539/ijbm.v8n22p50

Magness, V. (2008). Who are the stakeholders now? An empirical examination of the Mitchell, Agle, and Wood theory of stakeholder salience. Journal of Business Ethics, 83(2), 177-192. https://doi. org/10.1007/s10551-007-9610-2

Mascena, K., \& Stocker, F. (2020). Stakeholder Management: State of the Art and Perspectives. Future Studies Research Journal: Trends and Strategies, 12(1), 1-30. Retrieved from https://doi.org/https:// doi.org/10.24023/FutureJournal/2175- 5825/2020.v12i1.490

Meneghetti, F. K. (2011). O que é um ensaio-teórico? Revista de Administração Contemporânea, 15(2), 320-332. Retrieved from https://doi.org/10.1590/s1415-65552011000200010

Mills, C. W. (1940). Situated actions and vocabularies of motive. American Sociological Review, 5(6), 904-913. Retrieved from https:// doi.org/10.4324/9780203787120

Mitchell, R. K., Agle, B. R., \& Wood, D. J. (1997). Toward a theory of stakeholder identification and salience: defining the principle of who and what really counts. Academy of Management Perspectives, 22(4), 853886. Retrieved from https://doi.org/10.5465/amr.1997.9711022105

Parmar, B. L., Freeman, R. E., Harrison, J. S., Wicks, A. C., Purnell, L., \& Colle, S. (2010). Stakeholder Theory: The State of the Art. The Academy of Management Annals, 4(1), 403-445. Retrieved from https://doi.org/10.5465/19416520.2010.495581

Patriotta, G., Gond, J.-P., \& Schultz, F. (2011). Maintaining legitimacy: Controversies, orders of worth, and public justifications. Journal of Management Studies, 48(8), 1804-1836. Retrieved from https://doi. org/10.1111/j.1467-6486.2010.00990.x

Perkiss, S., \& Moerman, L. (2020). Hurricane Katrina: Exploring justice and fairness as a sociology of common good(s). Critical Perspectives on Accounting, 67(102022). Retrieved from https://doi.org/10.1016/j. сра.2017.11.002

Phillips, R. A., Barney, J. B., Freeman, R. E., \& Harrison, J. S. (2019). Stakeholder Theory. In J. S. Harisson, J. B. Barney, R. E. Freeman, R. A. Phillips (Eds.), The Cambridge Handbook of Stakeholder Theory. Cambridge, UK: Cambridge University Press.

Phillips, R., Freeman, R. E., \& Wicks, A. C. (2003). What Stakeholder Theory Is Not. Business Ethics and Strategy, Volumes I and II, 13(4), 479-502.

Schneider, T., \& Sachs, S. (2017). The Impact of Stakeholder Identities on Value Creation in Issue-Based Stakeholder Networks. Journal of Business Ethics, 144(1), 41-57. https://doi.org/10.1007/s10551-015-2845-4

Smircich, L., \& Stubbart, C. (1985). Strategic Management in an Enacted World. Academy of Management Review, 10(4), 724-736. Retrieved from https://doi.org/10.5465/amr.1985.4279096

Stocker, F., \& de Mascena, K. M. C. (2019). Orientation and managing for stakeholders in the decision-making process. Revista de Gestao e Secretariado, 10(1), 167-191. Retrieved from https://doi.org/10.7769/ gesec.v10i1.864

Suddaby, R. (2014). Editor's comments: Why theory? Academy of Management Review, 39(4), 407-411. 
Sulkowski, A. J., Edwards, M., \& Freeman, R. E. (2018). Shake Your Stakeholder: Firms Leading Engagement to Cocreate Sustainable Value. Organization and Environment, 31(3), 223-241. Retrieved from https://doi.org/10.1177/1086026617722129

Susen, S. (2017). Remarks on the nature of justification: A sociopragmatic perspective. In C. Cloutier, J. P. Gond, \& B. Leca (Eds.), Justification, Evaluation and Critique in the Study of Organizations (Research in the Sociology of Organizations, Vol. 52, pp. 349-381). Bingley, UK: Emerald Publishing Limited. Retrieved from https://doi. org/10.1002/smj.822

Thévenot, L. (2002). Conventions of co-ordination and the framing of uncertainty. In E. Fullbrook (Ed.), Intersubjectivity in Economics: Agents and Structures (pp. 181-197). London, UK: Routledge.

Thévenot, L. (2019). What engages ? The sociology of justifications, conventions, and engagements, meeting norms. La Revue Des Droits de l'homme, 16, 1-16. Retrieved from https://doi.org/10.4000/ revdh.7114

Thévenot, L., Moody, M., \& Lafaye, C. (2000). Political Practice and Culture in French and American Environmental Disputes. In M. Lamont, \& L. Thévenot (Eds.), Rethinking comparative cultural sociology: repertoires of évaluation in France and the United States (pp. 229272). Cambridge, UK: Cambridge University Press.

Wood, D. J., Mitchell, R. K., Agle, B. R., \& Bryan, L. M. (2018). Stakeholder Identification and Salience After 20 Years: Progress, Problems, and Prospects. Business and Society, 1-50. Retrieved from https://doi. org/10.1177/0007650318816522

Ylä-Anttila, T., \& Luhtakallio, E. (2016). Justifications analysis: Understanding moral evaluations in public debates. Sociological Research Online, 21(4), 1-15. Retrieved from https://doi.org/10.5153/ sro.4099

Helna Almeida de Araujo Góes

ORCID: https://orcid.org/0000-0001-5485-9353

M.Sc. student in Business Management at Business Management Graduate Program of the Universidade Federal do Paraná (UFPR)

E-mail: helna@ufpr.br

Germano Glufke Reis

ORCID: https://orcid.org/0000-0001-8884-5734

Ph.D. in Business Administration from the São Paulo University (USP); Professor of Business Management at Universidade Federal do Paraná (UFPR).

E-mail: glufkereis@ufpr.br

Gustavo Abib

ORCID: https://orcid.org/0000-0002-8768-9669

Ph.D. in Business Management from the Federal University of Rio Grande do Sul (UFRS); Associate Professor at the Business Management Graduate

Program of the Universidade Federal do Paraná (UFPR).E-mail: abib@ufpr.br 